\title{
DETERMINATION OF AIR QUALITY, THROUGH THE CUMULATIVE MEASUREMENT OF THE CONCENTRATION OF THE MATERIAL PARTICLES, IN A WORKSHOP FOR MAKING METAL CAST PARTS
}

\author{
Beatrice TUDOR, Viorel Mircea DRAGAN \\ "Dunarea de Jos" University of Galati, Romania \\ e-mail: beatrice.tudor@ugal.ro
}

\begin{abstract}
Material particles represent a category of air pollutants, which greatly affect human health, and include in their composition, nitrates, sulphates, organic carbon dust and salt. The paper presents determinations of the air quality, from different sectors, of a metal casting workshop. The determinations were made during the technological process of production, as well as during when the workshop does not have a production activity. In all cases, was monitored the variation of material particles (PM) concentrations. The measurements were made with the help of the particle counter, Fluke 985, the results obtained, being compared with the legislation in force, regarding safety and health at work.
\end{abstract} dust

KEYWORDS: air pollutants, material particles, air quality, organic carbon

\section{Introduction}

Material particles represent a category of air pollutants, which greatly affect human health. These include in their composition: nitrates, sulphates, organic carbon, elemental carbon, dust and salt. They can come from very different sources and have a number of specific morphological, chemical and physical properties.

The determination of the variability of the PM concentration, during a time interval shorter than one day, can be performed, with the help of continuous measurements. The suspended particles represent a complex mixture of very small particles and drops of liquid $[1,2]$.

The main sources of origin are:

- Natural sources: volcanic eruptions, rock erosion, sandstorms, and pollen dispersal.

- Anthropogenic sources: industrial activity, population heating system, thermoelectric power plants.

Road traffic contributes to the pollution with dust, produced by the tires of cars, both in stopping them and due to incomplete combustion.

The determinations of the air quality were made in a workshop of casting metal parts, in different workshops, intended for the technological process of forming-casting of castings, in order to determine the variation of PM concentrations, during the technological process. The monitoring of the air quality problems was carried out in different work areas, respectively, in the area of making alloy in the furnaces, the mould preparation area, the parts casting area, the debating-parts cleaning area, as well as during when the workshop having no production activity.

\section{General description of technological processes and flows}

Technological processes that take place in the workshop of casting of metal parts are: preparation of mixture for moulds; execution of moulds and cores; filling moulds and preparing them for casting; the casting in the mould; cooling forms; debate of the moulds, regeneration and cooling of the sand; blasting of castings parts; tensioning / normalizing of castings; cleaning castings.

Before casting the steel, is made the wood model gasket, within the modeling workshop, then made the shapes and cores are made of a mixture of quartz sand, binders and auxiliary materials. After pouring the molten metal into moulds, the castings are allowed to cool, then the parts are cleaned, within the cleaning workshop, where the technological 
additions, the alloy casting network, the feeder, are removed, by cutting with the oxy-acetylene flame, or is removed mixture, left on the surfaces, of the cast piece. This is done with pneumatic hammers or by blasting.

The workshop for the preparation of the moulds ensures the preparation of the mixture, making the moulds with mixture, their filling with liquid metal, the debate of the pieces after cooling, and their transfer to the cleaning workshop. The moulds and cores, made from mixtures of synthetic binders, with cold hardening, are coated with paint, resin based and water-based paint.

The cleaning workshop ensures the cleaning of the castings, the removal of the casting networks, and the technological additions. Secondary cleaning - it is executed after the heat treatment, in order to deliver the cast parts, to the beneficiary or to mechanical processing.

\section{Experimental results}

The composition of the dust is extremely changeable and can be associated with the following components: sulphur dioxide, carbon monoxide, nitrogen oxides and hydrocarbon burning residues.

From the point of view of health and the environment, the most harmful dust is made up of particles with a diameter of less than 10 microns, known as PM10. They penetrate deep into the respiratory system, reaching into the lungs, where they store the dangerous substances they carry.

About $60 \%$ of PM10 is made up of PM2.5 particles with a diameter below 2.5 microns. In this form, they can enter the pulmonary and blood cells.

Specifically, the body's defence cells, it confuses them with bacteria, and tries to kill them. As they do not represent bacteria, the immune system cannot "kill" them, and the result is a permanent inflammation of the lung tissue. Usually, these powders also contain active substances, which generate a process of lung disease, similar to that caused by smoking or aging. Long-term exposure to fine particulate pollution increases mortality, and the risk of cardiovascular diseases [5, 6].

The effects on human health are the same, and in the case of PM1 particles, which have a diameter of 1 micron.

PM2.5 represents the technical indicator, for the most dangerous suspended powders (dust wires), detectable in the air, especially in large cities. "2.5" refers to the size, and indicates a particle of maximum 2.5 microns. In contrast to the larger powders, classified as PM10 (i.e. particles with a size of at least 10 microns), powders of the PM2.5 category penetrate deep into the lungs, are difficult to remove and cause a reaction of the immune system [8].
This type of particles comes from the dust on the street, the nooks from thermal and industrial plants, the combustion of any kind, traffic or unprotected yards.

The reference method for the sampling and measurement of PM10 and PM2.5 is that laid down in standard EN 12341 "Ambient air. Standardized method for gravimetric measurement to determine the mass fraction of PM10 or PM2.5 of suspended particles" [3, 4].

Table 1. Norms - EN 12341

\begin{tabular}{|c|c|}
\hline $\begin{array}{c}\text { LAW no. } 104 \text { of June 15, } 2011 \\
\text { Suspended particles - PM10 }\end{array}$ \\
\hline \begin{tabular}{c|c} 
Limit \\
values
\end{tabular} & $\begin{array}{c}\mathbf{5 0} \boldsymbol{\mu g} / \mathbf{m}^{3} \text { - the daily limit value for } \\
\text { the protection of human health } \\
\mathbf{4 0} \mu \mathrm{g} / \mathrm{m}^{3}-\text { the annual limit value for } \\
\text { the protection of human health }\end{array}$ \\
\hline
\end{tabular}

\begin{tabular}{|c|c|}
\hline \multicolumn{2}{|r|}{$\begin{array}{l}\text { LAW no. } 104 \text { of June 15, } 2011 \\
\text { Suspended particles - PM2.5 }\end{array}$} \\
\hline $\begin{array}{l}\text { Target } \\
\text { value }\end{array}$ & $25 \mu \mathrm{g} / \mathbf{m}^{3}$ - annual target value \\
\hline $\begin{array}{l}\text { Limit } \\
\text { values }\end{array}$ & $\begin{array}{l}25 \mu \mathrm{g} / \mathbf{m}^{3} \text { - the annual limit value to } \\
\text { be reached by January } 1,2015 \\
\mathbf{2 0} \boldsymbol{\mu \mathrm { g } / \mathbf { m } ^ { 3 }} \text { - the annual limit value to } \\
\text { be reached by January } 1,2020\end{array}$ \\
\hline
\end{tabular}

The equipment used to determine the air quality inside the parts casting workshop is the Fluke 985 Particle Counter (Fig. 1). The Fluke 985 particle counter is an essential and professional tool, ideal for troubleshooting and monitoring indoor air quality issues, and checking the performance of the HVAC filter, and critical locations for ISO certification 5-9.

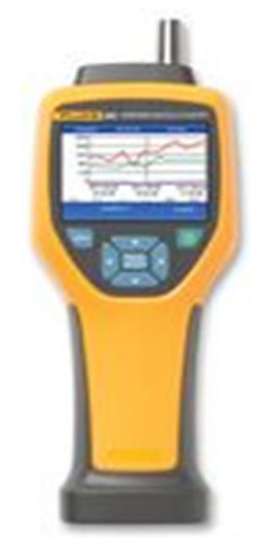

Fig. 1. Fluke 985 particle counter 
The workshop for casting the parts, is equipped with an installation for the removal and collection of the noxes. This equipment should be located beyond the work area, as it would exceed the noise level allowed by the rules of health and safety at work, in the proximity of work areas.

The workshop is equipped with a Donaldson DFPRO 8 filtration system. Following the installation of the filters for the capture and reduction of powders or noticed visible decreases in the intensity of the noxiousness in the working atmosphere $[10,11]$.
The paper presents the methods for determining dusts in the air in the working area. The monitoring of the air quality problems was done both during the development of the technological process activities, and while the workshop does not have a production activity, the data being compared, with the norms in force of the EN 12341 standard, "Ambient air". Standardized method, for gravimetric measurement, to determine the mass fraction of PM10 or PM2.5 of suspended particles [12].

The determinations were centralized, by sectors of activity, and represented in the following graphs.

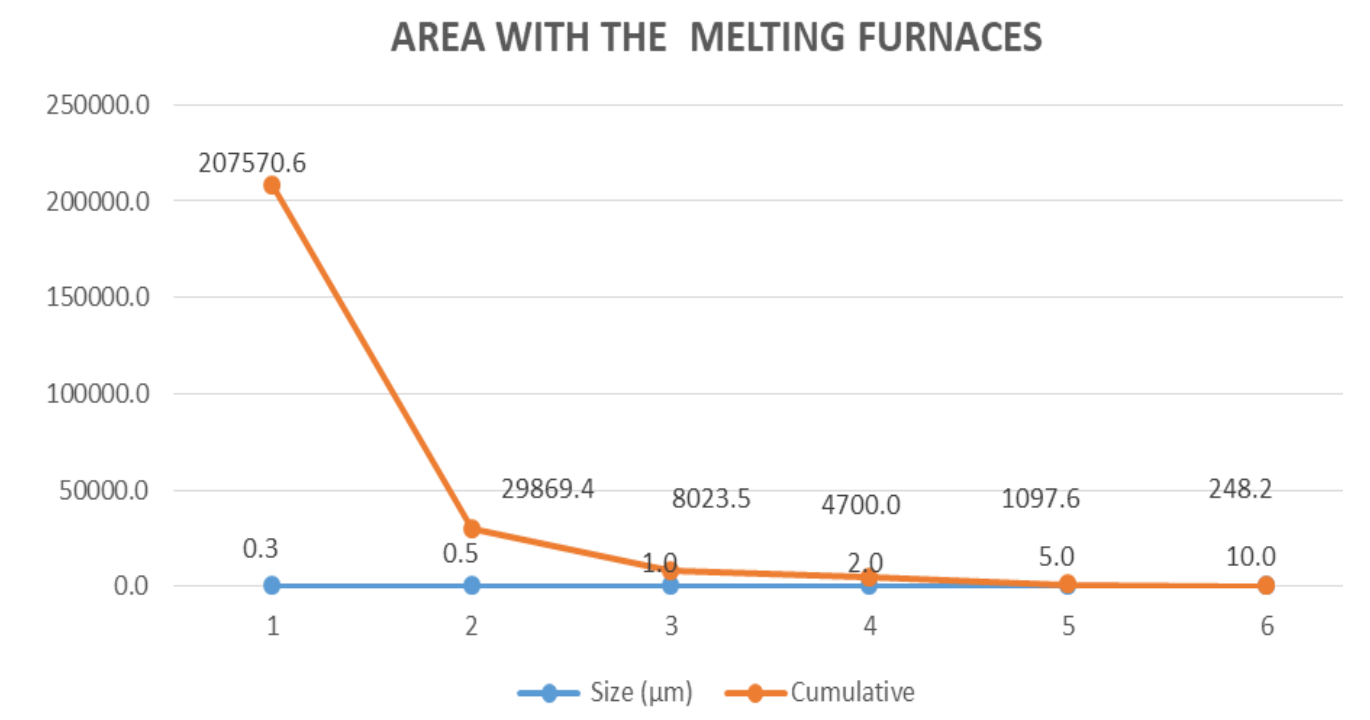

Fig. 2. Determinations of the cumulative values of particles in the alloys making sector

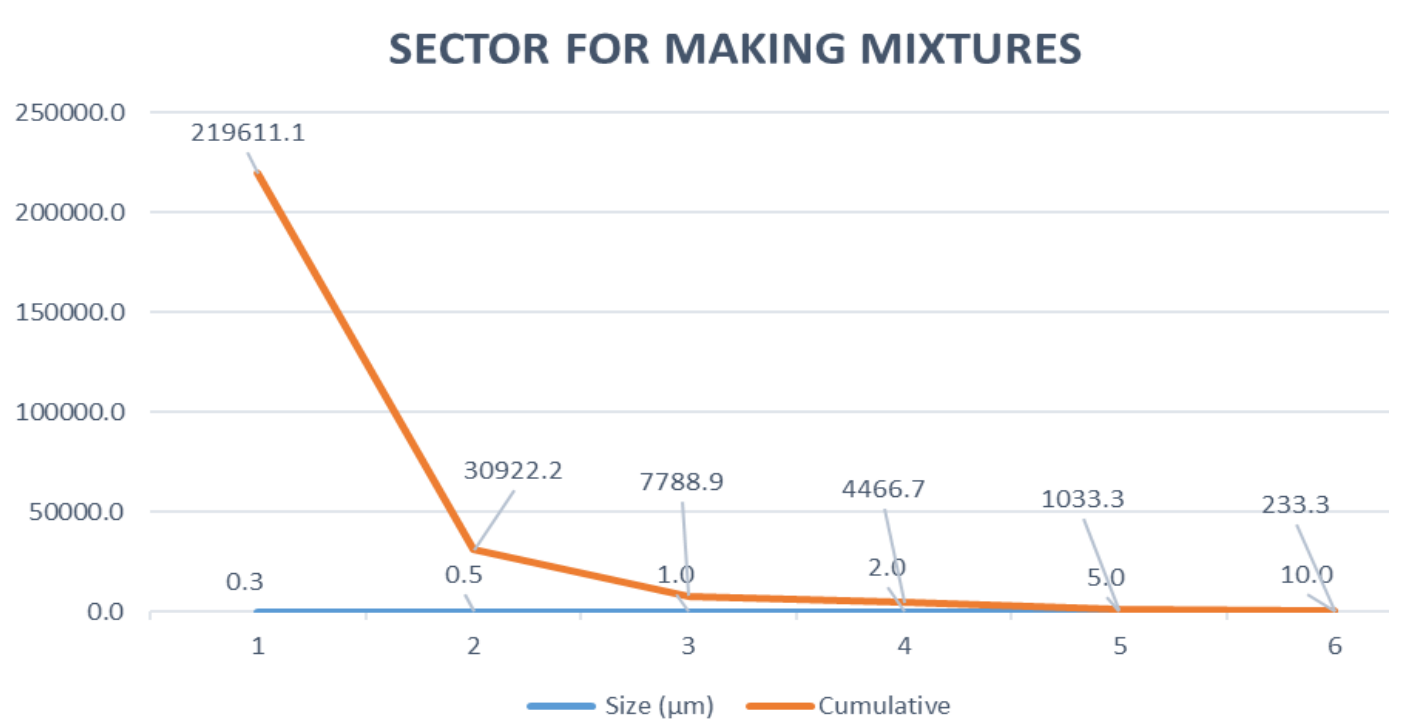

Fig. 3. Determination of the cumulative values of particles in the sector of moulds for casting parts

The coefficient of variability is very high for PM10, and for PM2.5, in the sectors of debating cast parts, and the realization of shapes from casting (Fig.
$3,5)$. These values show a very large variation during the experimental determination period, between these sectors, in working condition, and in resting state, that 
is, in the periods when we have no production activity (Fig. 6). Particles of $0.3 \mu \mathrm{m}$ are the most dangerous to health. The highest cumulative values of this kind of particles, were obtained, in the sector of debating cast parts from moulds.

Significant differences for PM10 and PM2.5 indices were obtained, between the recorded values, in the two activity areas, respectively in the casting sector, and the sector in which is making moulds from mixture.

The values obtained for PM10 and PM2.5 indices in air, during the experimental period, in the melting furnace area and in the alloy casting area, were relatively small, below the allowed limit (see Table 1), $50 \mu \mathrm{g} / \mathrm{m}^{3}$, according to with GD 592/2002.

\section{CASTING SECTOR}

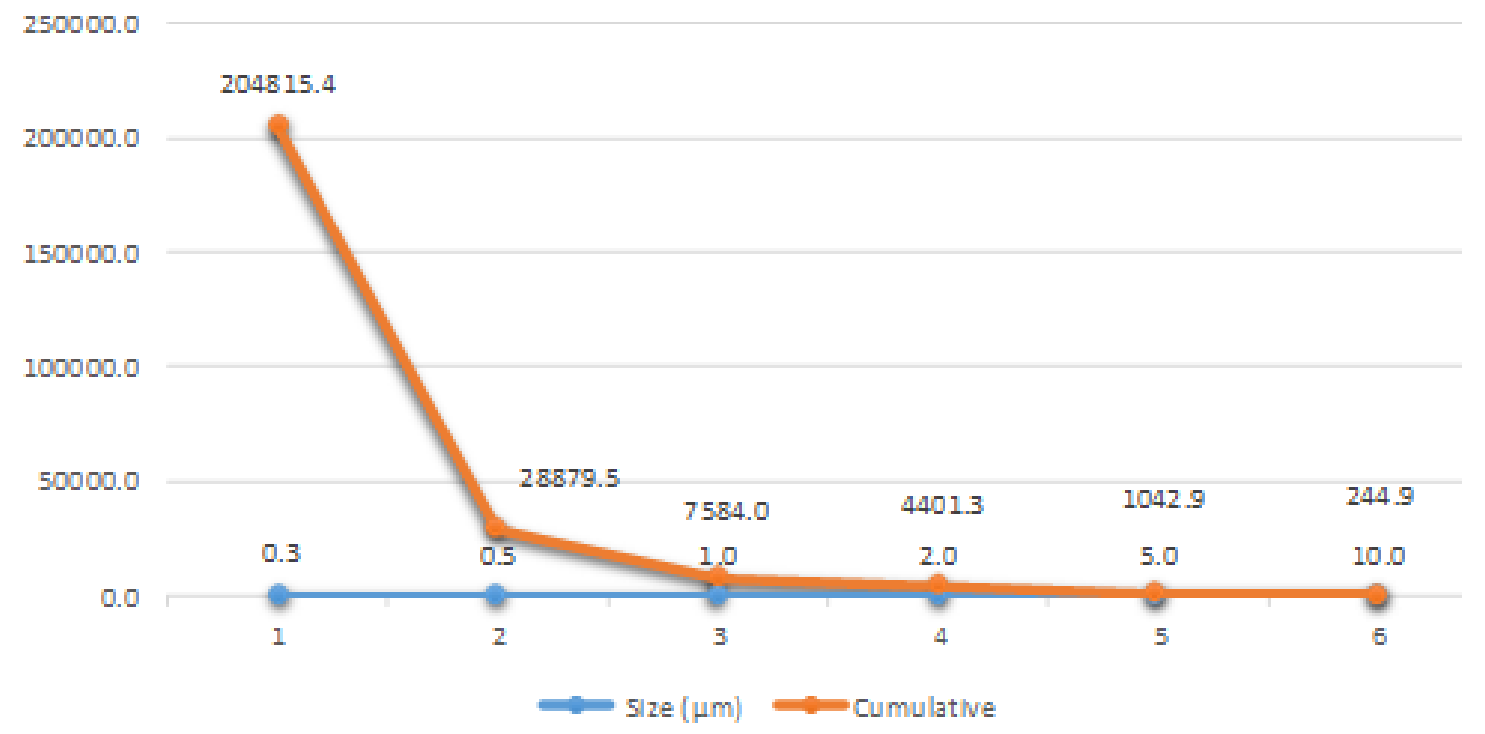

Fig. 4. Determination of the cumulative values of particles in the metal casting sector

\section{CLEANING SECTOR OF THE CASTING PARTS}

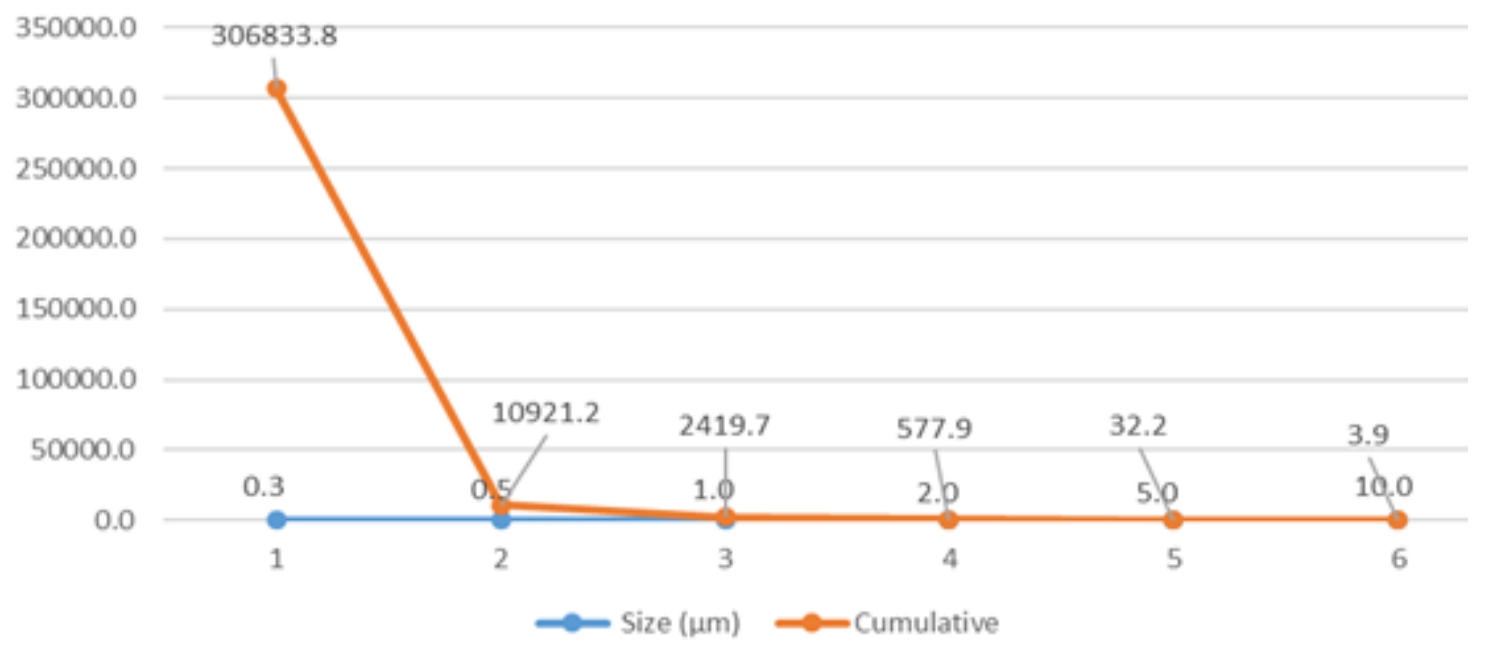

Fig. 5. Determination of the cumulative values of particles in the sector of debating and cleaning castings 


\section{WORKSHOP FOR MAKING THE PARTS WITHOUT PRODUCTION ACTIVITY}

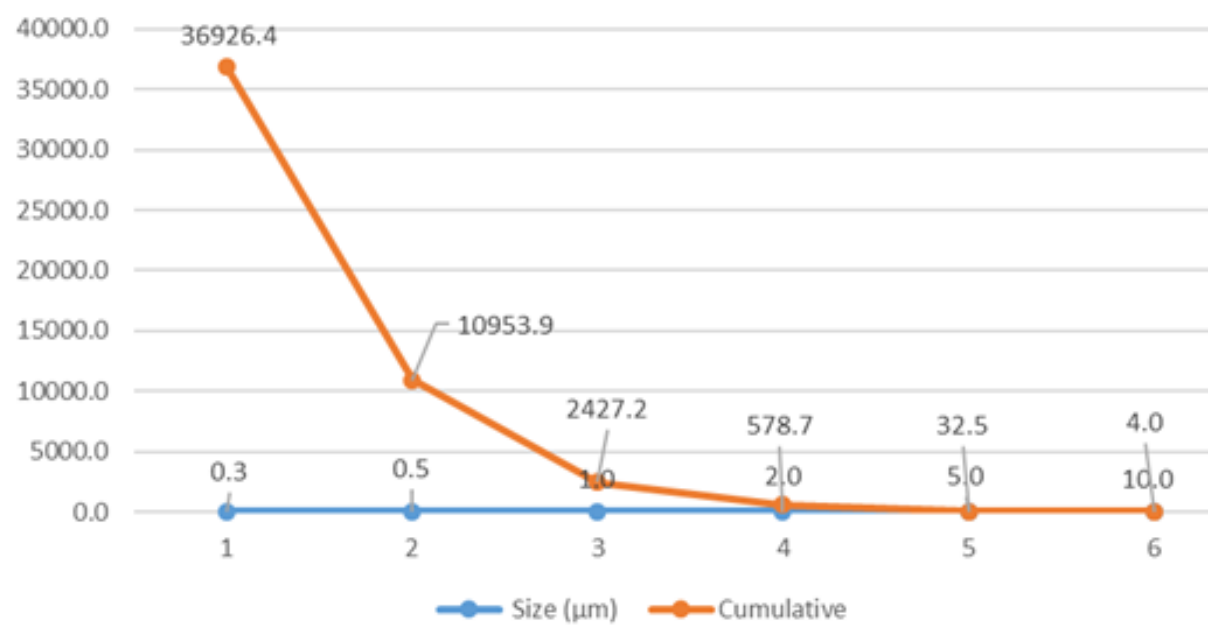

Fig. 6. Determination of the cumulative values of particles while the workshop is without production activity

\section{Conclusions}

The evaluation of the quality of the air imposed both the investigation of the conditions of the working environment, as well as the evaluation of the quality of the air inside the workshop of casting of the metallic pieces [7, 9].

During the period of experimental determination, there was a great variation, between the sectors of the making moulds from mixture, and debating the castings, in working condition, and in resting state, that is, during the periods when we have no production activity.

The highest cumulative values for $0.3 \mu \mathrm{m}$ particles it was obtaining in these areas. These particles are the most dangerous for health.

Following the interpretation of the results obtained, in comparison with the norms in force, regarding the health and safety of the work, it is proposed the following organizational measures in the casting workshop. masks;

- training on the need to use goggles and dust

- periodic medical check with thematic detection of the diseases that manifest or are about to be installed in the respiratory system;

- making determinations for the quantity of powders in the workplace atmosphere with the regularity required - maintaining cleanliness to avoid accumulation of dust or other particles that can be entrained by air currents by law; workplace.

\section{References}

[1]. Wallace L., Howard-Reed C., Continuous monitoring of ultrafine, fine, and coarse particles in a residence for 18 months in 1999-2000, J. Air Waste Manage. Assoc., 52, p. 828-844, 2002.

[2]. ***, Air Quality Criteria for Particulate Matter Volume I of II, October 2004, EPA/600/P-99/002aF, National Center for Environmental Assessment-RTP Office, 2004,

[3]. ***, SR EN 12341:2002 Determinarea fracţiei PM 10 de materii sub formă de pulberi suspensie. Metoda de referinţă şi proceduri de încercare in situ pentru demonstrarea echivalenţei la metoda de măsurare de referință, 2002.

[4]. ***, Ordinul MAPM nr. 592/25.06.2002 pentru aprobarea Normativului privind stabilirea valorilor limită, a valorilor de prag şi a criteriilor şi metodelor de evaluare a dioxidului de sulf, monoxidului de carbon şi ozonului în aerul înconjurător, published in Monitorul Oficial, nr. 765/21.10.2002.

[5]. Chang H. Y., Principles of Air Pollution. Human Health II Health effects from $\mathrm{O}_{3}, \mathrm{NO}_{X}, \mathrm{SO}_{2}, \mathrm{PM}, \mathrm{CO}, \mathrm{Pb}, \mathrm{HAPs}$, available at www.envsci.rutgers.edu/ pap_ta/Health\%20Effects\%20II.ppt,

(15.03.05).

[6]. Mănescu S., Igiena mediului, Ed. Medicală, Bucuresti, 1991.

[7]. Rojanski V., et al., Protecţia şi Ingineria Mediului, Ed. Economică, Bucureşti, 1997.

[8]. ***, Health Aspects of Air Pollution with Particulate Matter, Ozone and Nitrogen Dioxide, Report on a WHO Working Group Bonn, Germany, 13-15 Jan.

[9]. Ciplea L. I., Ciplea Al., Environmental Pollution, Technical Publishing, Bucharest, 1978.

[10]. Căluianu S., Measurement and control of air pollution, Matrix Rom Publishing House, Bucharest, 1999.

[11]. Ştefan S., Atmospheric aerosol physics, ALL Publishing House, Bucharest, 1998.

[12]. Mulholland G. W., Hartman A. W., Hembree G. C., Marx E., Lettieri T. R., Development of a One-Micrometer Diameter Particle Size Standard Reference Material, Journal of research of the National Bureau of Standards, 90, p. 3-26, 1985. 